\title{
EFFECT OF VITAMIN E AND COD LIVER OIL SUPPLEMENT WITH BIVALENT OIL BASED VACCINE OF NEWCASTLE DISEASE AND INFECTIOUS BRONCHITIS DISEASE ON IMMUNE RESPONSE OF THE BROILERS.
M. T. ABDULWAHID ${ }^{(1)}$
A. H. ZAHID ${ }^{(1)}$
M. J. KADHUM ${ }^{(2)}$
LECTURER
PROFESSOR
RESEARCHER

(1)College of Veterinary Medicine/Baghdad University. dr.m.t.abdulwahid@gmail.com

(2)Department of Biology and Medicine Supervision/Veterinary Directorate.

\begin{abstract}
This study was aimed to enhance the immune response of the broilers by vitamin $E$ and Cod liver oil supplement with locally inactivated bivalent vaccine of Newcastle disease and Infectious bronchitis viruses. One hundred and twenty broiler chicks Ross 308 were divided to four groups at 30 chicks of each group. The $2^{\text {nd }}$ group was vaccinated with $0.5 \mathrm{ml} / \mathrm{chick}$ of locally inactivated ND-IB vaccine at 5 days old. The $3^{\text {rd }}$ group was vaccinated with $0.5 \mathrm{ml}$ locally ND-IB vaccine and $0.1 \mathrm{ml} / \mathrm{chick}$ of VE. The $4^{\text {th }}$ group was vaccinated with $0.5 \mathrm{ml}$ of locally NDIB vaccine and $0.1 \mathrm{ml} / \mathrm{chick}$ of Cod liver oil, while the first group was left without vaccination as a control group. All groups were vaccinated with attenuated ND-IB at 3 days old and attenuated IBD at 14 days old. The results of ELISA test revealed that the $3^{\text {rd }}$ and $4^{\text {th }}$ groups showed significantly increased $(P \leq 0.05)$ in Ab titers against ND virus at aged 35 days, also, the $4^{\text {th }}$ group showed significantly $(P \leq 0.05)$ increased in $A b$ titers against IB virus at day 35 of age as compared with the other groups. The $4^{\text {th }}$ group showed a significant $(P \leq 0.05)$ increased in bursal index as compared with the other groups. The results of challenge test revealed that vaccinated groups resist the velogenic ND and IB viruses with relatively high productive range particularly the $4^{\text {th }}$ group as compared with other groups. In conclusion, the VE and Cod liver oil supplement with local bivalent oil based vaccine of ND and IBV may enhance the immune response of the broilers particularly the $4^{\text {th }}$ group which vaccinated with $0.5 \mathrm{ml}$ of local bivalent oil based vaccine of ND-IB vaccine and $0.1 \mathrm{ml}$ Cod liver oil.
\end{abstract}

Keywords: Inactivated ND+IB vaccine, Vitamin E, Cod liver oil, immune response, broilers

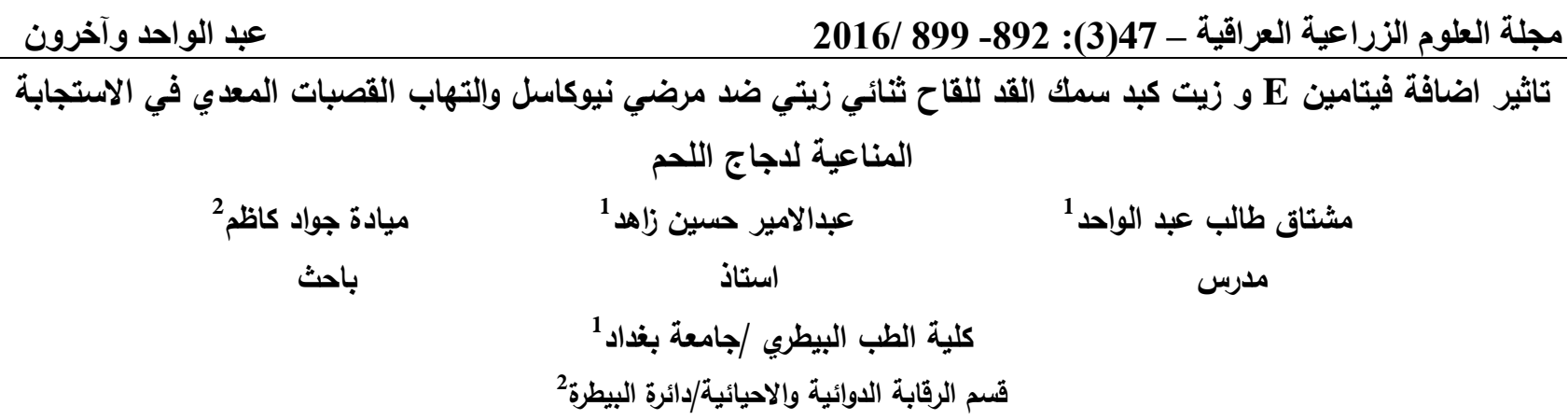

أجريت هذه التجربة لتحسين الاستجابة المناعية لاجاج اللحم باضافة فيتامين E و زيت كبد سمك القد للقاح مبطل ثنائي زيتي محلي ضد مرضي نيوكاسل والتهاب

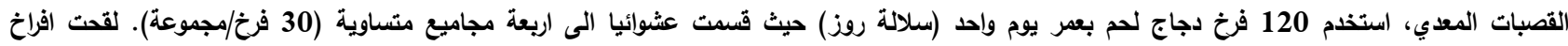

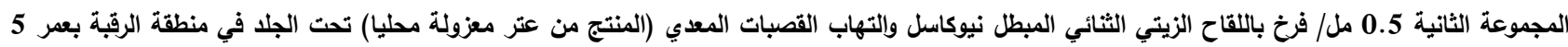

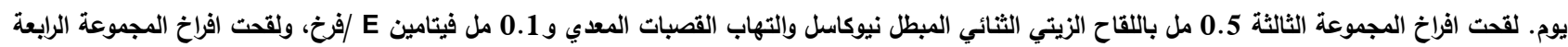
0.50

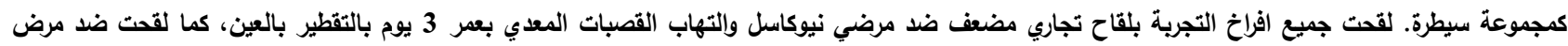

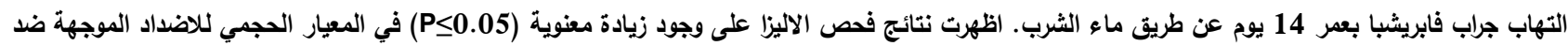

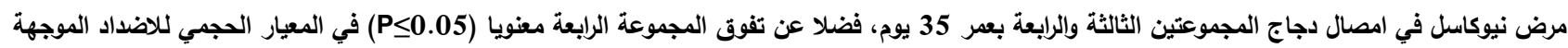

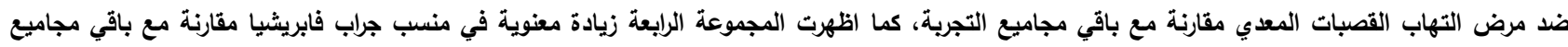

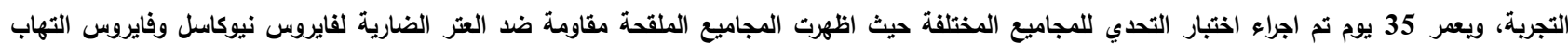

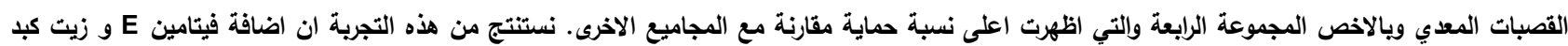

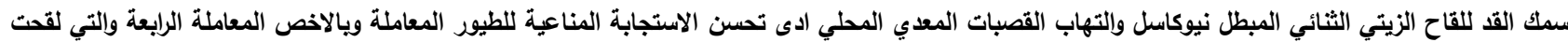

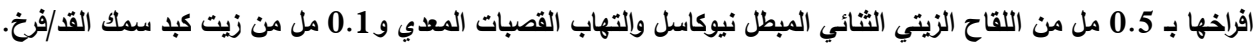

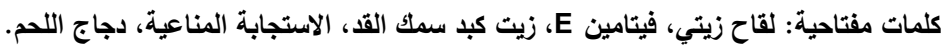




\section{INTRODUCTIO}

In commercial poultry production, oxidative stress has been associated with the deterioration of many traits including health, growth, reproduction and immunity. Sahin and Kucuk, (42) noted that antioxidant vitamins such as vitamin $\mathrm{E}, \mathrm{A}$ and $\mathrm{C}$ have been used to ameliorate the effects of environmental stress. Vitamin E (VE) is a potent antioxidant; it has the ability to prevent oxidative damage to cell through inactivation of free radicals and reactive oxygen species (54). This ability of VE is similar to the observations of (2) who concluded that VE has a good work to maintain the integrity of body tissues from damages and has been proposed as a major antioxidant in plasma membranes of all cells and sub-cellular organs. Vitamin E may affect the maintenance of immunocompetence through multiple functions by acting directly on the immune cell or by indirectly altering metabolic and endocrine parameters, which in turn influence immune function (9). Also, several researchers (8) proved that VE prevents the oxidation of unsaturated fatty acids which was led to stimulate cellular and humoral immunity when different bacterial infection was attacked the body. Surai et al., (6) reported that VE is functioning as a chain-breaker and free radical crusher. Cod liver oil (CLO) is a rich source of omega-3 fatty acids which are essential fatty acids (25). It is not made by the body and must be supplied by the diet or supplements. Scientists first became interested in omega-3 fatty acids when it was reported that the Eskimo population, who eat a diet rich in fish oil, had a low rate of heart disease. Cod liver oil contains two types of omega-3 fatty acids: DHA (docosahexaenoic acid) and EPA (eicosapentaenoic acid) (24). However, n-3 PUFA increase both the susceptibility of cellular membranes to the induction of oxidative stress in animal organisms (34). Dietary long-chain n-3 polyunsaturated fatty acids (LC-PUFA; n-3), eicosapentanoiec acid (EPA; 20:5) and docosahexanoeic acid (DHA; 22:6) have been reported prevent cardiovascular disease, improve the immune response, and reduce the serum cholesterol concentration (45). Chicken embryo tissues contain a high proportion of polyunsaturated fatty acids (16). Omega-3 fatty acids such as CLO, is essential for maintenance of normal health (38). Several studies confirmed many positive effects of dietary n-3 PUFA including immune response, lipid peroxidation, and antioxidative properties $(53,17)$. Omega-3 PUFAs are known to possess anti-inflammatory properties in humans $(11,12)$ and chickens $(26)$. Failure of health maintenance may cause great economic loss among the most important traits egg production, egg fertility and hatchability for chicken breeder farms. Although mass vaccination against Newcastle disease (ND), infectious bursal disease (IBD) and infectious bronchitis (IB) has been practiced throughout the commercial poultry industry, outbreaks of those diseases still occur occasionally; hence, vaccination responses and enhancement of immune system are matters of great concern, thus using VE may enhance immune response (31). Day old progeny chicks are being sold by many hatcheries with unknown status of parental immunity against various prevalent infections particularly against ND or IB. Vaccination schedules followed at almost all farms thus becomes ineffective and therefore, commercial broilers remain vulnerable to the natural antigen infection due to the neutralization of live virus vaccine by maternal antibodies (51). Dietary Fish oil levels below 3.5\% increased the $\mathrm{Ab}$ titer in laying hens (17). Also, the antibody levels were higher in hens fed oils rich in omega-3 PUFA than in hens fed oil rich in omega-6 PUFA (33). Some studies referred that a moderate intake of omega-3 PUFA could enhance the antioxidative properties including the activity of glutathione peroxidase in experimental animals and reduce serum lipid peroxidation $(17,32$, and 27$)$. The objective of the present study was to research the effects of vitamin $\mathrm{E}$ and Cod liver oil supplement with locally inactivated bivalent vaccine of ND and IB disease on immune response of the broilers.

\section{MATERIALS AND METHODS:}

One hundred twenty broiler chicks one day old Ross 308 were divided randomly into four groups, each group contained 30 chicks were housed in four separated rooms in the animal house of the Department of Biology and Medicine Supervision/ Veterinary Directorate. First group non-vaccinated which was considered as a control, Second group was vaccinated with $0.5 \mathrm{ml}$ inactivated ND-IB vaccine (Local strains) at 5 days old via subcutaneous route. Third group was vaccinated with $0.5 \mathrm{ml}$ inactivated ND-IB vaccine (Local strains) and $0.1 \mathrm{ml}$ vitamin $\mathrm{E}$ at 5 days old via subcutaneous route. While, fourth group was vaccinated with $0.5 \mathrm{ml}$ inactivated ND-IB vaccine (Local strains) and $0.1 \mathrm{ml}$ Cod liver oil at 5 days old via subcutaneous route injection. Each room floor was covered with suitable litter (softwood shaving), lighting and ventilation were controlled according to recommendations. Broiler chicks were kept under a 24 hours constant lighting schedule. Feed and water were supplied ad libitum. The diet was formulated according to the recommendations of (37). All groups except first group were vaccinated with $0.03 \mathrm{ml} /$ chick attenuated ND-IB (commercial vaccine) at 3 days 
old via ocular route. Also, all groups were vaccinated with attenuated IBD at 14 days old via drinking water route.

The materials and the vaccines used in this study:

1- Vitamin E (Dl-alpha tocopheryl acetate - oily form) manufactured by Natural Wealth Nutrition Corporation - USA.

2- Cod Liver oil produced by Vitex Pharmaceuticals Pty Ltd-Australia.

3- Locally ND-IB inactivated oil emulsified vaccine, local ND AG 68 strain contains $9.2 \log 10$ $\mathrm{EID}_{50} / \mathrm{ml}$. IB (QX and Variant 2) isolated strains contain 7.5 and $7.2 \log 10 \mathrm{EID} 50 / \mathrm{ml}$ respectively before inactivation.

4- Volvac ${ }^{\circledR}$ ND-IB MLV (Boehringer IngelheimHQ Germany) is a freeze dried modified live virus vaccine, prepared with LaSota strain of ND and Massachusetts serotype of IB. Titer: not less than $10^{5.5} \mathrm{EID}_{50} /$ dose of ND and $10^{3.9} \mathrm{EID}_{50} /$ dose of IB. 5- Volvac ${ }^{\circledR}$ IBD MLV (Boehringer Ingelheim): is a freeze dried modified live virus vaccine, prepared with a Lukert Intermediate virus strain for Gumboro disease (IBD). Titer: $10^{5.4} \mathrm{TID}_{50} /$ dose of the vaccine virus. A total of 40 blood samples (10 samples per group) were randomly collected from the wing vein of birds at 7, 14, 21, 28 and 35 days of age for ELISA test to determine the antibody titer of NDV and IBV, kits ProFLOK ${ }^{\circledR}$ PLUS Synbiotics Corporation -San Diego/USA was used in this study. After coagulation, the blood was centrifuged at $2300 \mathrm{rpm}$ for 5 minutes to obtain the serum. The serum samples were frozen at $-20^{\circ} \mathrm{C}$ until analyzed (7). Five birds were tacked randomly from each group to sacrifice at 7,21 and
35 days of age after weighed individually to determine body weights for bursa index to evaluate the effect of ND and IB vaccine. Following a thorough visual appraisal, the bursa of Fabricious was immediately removed, dry and individually weighed and calculated according to the formula: Organ index $=$ organ weight $(\mathrm{g}) / \mathrm{BW}(\mathrm{g}) \times 100$ (44). At 35 days old, ten birds were taken from each group for challenge test with virulent viruses of ND and IB diseases. These birds were divided into two groups, the first group was included twenty birds (five birds for each group) were challenged with dose $0.5 \mathrm{ml}$ of the virulent IB virus (field Variant 2 Strain) contained $10^{5.0} \mathrm{ELD}_{50}$ / bird. Another twenty birds (five birds for each group) were challenged with dose $0.5 \mathrm{ml}$ of the virulent ND virus contained $10^{9.1} \mathrm{ELD}_{50} /$ bird. All birds were remained under observation for ten days post challenge, clinical signs, morbidity rate, mortality rate and gross lesions were recorded. The data were submitted to statistical analysis ANOVA followed by least significant differences (L.S.D) were used to be differentiated among means of results, then the data were calculated as per the statistical program (SPSS) (48).

\section{RESULTS AND DISCUSSION:}

Data of Table 1 indicated that significant $(P \leq 0.05)$ differences in antibody titer among groups, the fourth group which vaccinated with inactivated ND IB vaccine (Local strains) and Cod liver oil showed significant $(\mathrm{P} \leq 0.05)$ increased in antibody titer against ND virus at age 7,28 and 35 days as compared with the second, third and control group, they were $3371.2 \pm 137.281,3060.4 \pm 23.262$ and $4252.2 \pm 240.393$, respectively.

Table 1. Mean \pm standard error of antibody titer against Newcastle Disease Virus measured by ELISA for different groups.

\begin{tabular}{|c|c|c|c|c|c|}
\hline Groups & $\begin{array}{c}\text { First group } \\
\text { (Control) }\end{array}$ & & $\begin{array}{l}\text { Second group } \\
\text { Vaccinated with } \\
0.5 \text { ml inactivated } \\
\text { ND+IB vaccine } \\
\text { (Local strains) }\end{array}$ & $\begin{array}{c}\text { Third group } \\
\text { Vaccinated with } \\
\text { 0.5 ml inactivated } \\
\text { ND+IB vaccine } \\
\text { (Local strains) and } \\
0.1 \text { ml vitamin } \mathrm{E} \\
\end{array}$ & $\begin{array}{c}\text { Fourth group } \\
\text { Vaccinated with } \\
0.5 \text { ml inactivated } \\
\text { ND+IB vaccine } \\
\text { (Local strains) and } \\
\text { 0.1 ml Cod liver oil }\end{array}$ \\
\hline 7 days & $5382.4 \pm 84.598$ & $\overline{\mathbf{B}}$ & $\begin{array}{l}5854.6 \pm 183.357 \text { A } \\
\end{array}$ & $\begin{array}{ll}5278.2 \pm 88.017 & \text { B }\end{array}$ & $5371.8 \pm 151.215$ В \\
\hline 14 days & $600.2 \pm 17.811$ & D & $1267.4 \pm 28.857 \quad \mathrm{C}$ & $1546.2 \pm 130.082$ В & $3371.2 \pm 137.281$ A \\
\hline 21 days & $357.4 \pm 26.464$ & D & 1888.4 $\pm 73.857 \quad$ A & $1120.6 \pm 20.536 \quad C$ & $1272.8 \pm 5.004 \quad$ B \\
\hline 28 days & $250.2 \pm 21.425$ & $\mathbf{C}$ & $2563.4 \pm 121.733$ B & $2380.2 \pm 136.809$ В & $3060.4 \pm 23.262$ \\
\hline 35 days & $173.4 \pm 5.617$ & C & $3297.6 \pm 114.602$ В & $4131.6 \pm 163.615 A$ & $4252.2 \pm 240.393 A$ \\
\hline
\end{tabular}

Different large letters horizontally refer to significant differences at level $(\mathrm{P} \leq 0.05)$ among mean of groups.

The same table revealed that the third group significantly $(\mathrm{P} \leq 0.05)$ increased in antibody titers at age 14 and 35 days as compared with the second and control group were $1546.2 \pm 130.082$ and $4131.6 \pm 163.615$, respectively, while, there were no significant $(\mathrm{P}>0.05)$ difference between the third and fourth treatments at 35 days old. Data of table 2 revealed no significant differences $(\mathrm{P}>0.05)$ in antibody titer among treatment groups at 7 days.
While, the $2^{\text {nd }}, 3^{\text {rd }}$ and $4^{\text {th }}$ groups were recorded a significant $(\mathrm{P} \leq 0.05)$ increased in $\mathrm{Ab}$ titer against IB virus at 14, 21, 28 and 35 days of age as compared with control group. The fourth group significantly $(\mathrm{P} \leq 0.05)$ higher in $\mathrm{Ab}$ titers against IB virus at age 35 days as compared with the second, third and control group were 4822.8 \pm $62.107,4700.2 \pm 12.793,4017.8 \pm 21.77$ and $104.2 \pm$ 2.517 , respectively. The increment of antibody 
titers in third group as compared with the second group and control could be obtained due to the act of VE in activation and stimulation B-lymphocyte which led to increase antibody titers. Also, vitamin E was protected cells of immune system from degeneration due to excessive lipoperoxides, this view was showed by other researchers, $(52,36)$. Furthermore, vitamin E provided as an adjuvant, also, improved immune responses (19, 21). Abdulwahid (1) concluded that in Ovo vitamin E inoculation enhanced both humoral and cellular effectors components of the avian immune system. On the other hand, there was evidence that prostaglandins may regulate immune responses; elevated levels of prostaglandins might be immune suppressive (47). Therefore vitamin E might play a vital role in down regulating prostaglandins production by antagonizing the peroxidation of arachidonic acid and limiting the entry of precursors into the prostaglandins, therefore, VE considered important in dampening prostaglandins (35). The researchers $(22,50)$ confirmed that estimation antibody titers in birds give good evidence to appointment immunity of birds against Newcastle disease virus. These positive results indicated that the effect of $\mathrm{VE}$ in preservation of the immune cells by inhibiting free radicals formation as product due to cellular immune response during phagocytosis process against microorganisms when body attacked (46). Vitamin E supplementation of progenitors improves antibody titers in the chicks (23).

Table 2. Mean \pm standard error of antibody titer against Infectious Bronchitis Disease Virus measured by ELISA for different groups.

\begin{tabular}{|c|c|c|c|c|c|c|c|c|}
\hline \multirow[t]{2}{*}{$\begin{array}{c}\text { Groups } \\
\text { Age } \\
7 \text { days }\end{array}$} & \multicolumn{2}{|c|}{$\begin{array}{c}\text { First group } \\
\text { (Control) }\end{array}$} & \multicolumn{2}{|c|}{$\begin{array}{l}\text { Second group } \\
\text { Vaccinated with } \\
0.5 \text { ml inactivated } \\
\text { ND+IB vaccine } \\
\text { (Local strains) }\end{array}$} & \multicolumn{2}{|c|}{$\begin{array}{c}\text { Third group } \\
\text { Vaccinated with } \\
\text { 0.5ml inactivated } \\
\text { ND+IB vaccine } \\
\text { (Local strains) and } \\
\text { 0.1 ml vitamin E } \\
\end{array}$} & \multicolumn{2}{|c|}{$\begin{array}{c}\text { Fourth group } \\
\text { Vaccinated with } \\
\text { 0.5ml inactivated } \\
\text { ND+IB vaccine } \\
\text { (Local strains) and } \\
\text { 0.1 ml Cod liver oil }\end{array}$} \\
\hline & $2061.8 \pm 72.78$ & $\mathbf{A}$ & $2088.8 \pm 42.463$ & $\mathbf{A}$ & $2006.2 \pm 85.272$ & $\mathbf{A}$ & $2032.0 \pm 62.761$ & $\mathbf{A}$ \\
\hline 14 days & $780.6 \pm 38.718$ & B & $1337.6 \pm 25.71$ & $\mathbf{A}$ & $1328.6 \pm 33.441$ & $\mathbf{A}$ & $1286.4 \pm 23.911$ & $\mathbf{A}$ \\
\hline 21 days & $308.0 \pm 27.511$ & $\mathbf{C}$ & $1363.4 \pm 58.979$ & B & $1511.4 \pm 30.114$ & $\mathbf{A}$ & $1561.6 \pm 34.343$ & A \\
\hline 28 days & $207.2 \pm 8.540$ & $\mathbf{C}$ & $2364.4 \pm 53.49$ & $\mathbf{A}$ & $2223.8 \pm 52.042$ & B & $2144.4 \pm 50.211$ & B \\
\hline 35 days & $104.2 \pm 2.517$ & D & $4017.8 \pm 21.77$ & C & $4700.2 \pm 12.793$ & B & $4822.8 \pm 62.107$ & $\mathbf{A}$ \\
\hline
\end{tabular}

Different large letters horizontally refer to significant differences at level $(\mathrm{P} \leq 0.05)$ among mean of groups.

These results of the current study as shown in Tables 1 and 2 demonstrated the highest antibody titers of fourth group as compared with other groups and control may be due to use of inactivated oil emulsified vaccine and CLO were improved the immune response in the body because liberation of the antigen was slow which led to continuous stimulation of the immune system. This is in agreement with other researchers $(39,49)$ who mentioned the inactivated oil emulsion vaccine is not adversely affected by maternal immunity as live vaccine and cod liver oil acts as adjuvant and disperse antigen slowly. In these circumstances, there is a progressive stimulation of the active immunity while the passive immunity declines and the immune system will gave the best protection with competence. Moreover, Cherian and Sim (13) reported that Omega-3 polyunsaturated fatty acids have very strong immunomodulatory activities; cod liver oil is the best single source of omega-3 fatty acid. On the other hand, Freidman (20) was examined the influence of omega-3 polyunsaturated fatty acids on immune response, he found the positive effect of omega -3 in the body of the growing turkey after vaccination against Newcastle disease which represented via significant increasing in antibody titers. The results as showing in Table 3 showed high significant differences $(\mathrm{P}<0.05)$ in the mean values of bursal index among the groups at 7, 21 and 35 days of age while the control group gave the lowest mean value at 21 and 35 days of age in compared with other treatment groups, as well as the fourth group was recorded significant $(\mathrm{P} \leq 0.05)$ increased in bursa index at the day 35 of age as compared with the third, second and control, they were $0.519 \pm 0.054$ as compared with $0.456 \pm 0.052$, $0.396 \pm 0.051$ and $0.016 \pm 0.001$, respectively. The interpretation for this finding is that when the chicks were vaccinated with inactivated ND-IB vaccine (Local strains) and adding vitamin $\mathrm{E}$ or cod liver oil during a short period led to stimulation of the bursa, this process struggled the function of B-lymphocytes inside the bursa consequently this will positively affect for the production of antibodies against NDV and IBV, while the first group (unvaccinated chicks) showed atrophy of bursa which it was embarrassed the humeral immune response. 
Table 3. Mean \pm standard error bursa index of for different groups.

\begin{tabular}{|c|c|c|c|c|c|c|c|c|}
\hline \multirow[b]{2}{*}{$\begin{array}{r}\text { Groups } \\
\text { Age }\end{array}$} & \multicolumn{2}{|c|}{ First group (Control) } & \multicolumn{2}{|c|}{ Second group } & \multicolumn{2}{|c|}{ Third group } & \\
\hline & \multicolumn{2}{|c|}{ Unvaccinated } & \multicolumn{2}{|c|}{$\begin{array}{l}\text { Vaccinated with } 0.5 \\
\text { ml inactivated ND+IB } \\
\text { vaccine (Local strains) }\end{array}$} & \multicolumn{2}{|c|}{$\begin{array}{l}\text { Vaccinated with } 0.5 \\
\text { ml inactivated ND+IB } \\
\text { vaccine (Local } \\
\text { strains) and } 0.1 \mathrm{ml} \\
\text { vitamin } \mathrm{E}\end{array}$} & \multicolumn{2}{|c|}{$\begin{array}{l}\text { Fourth group } \\
\text { Vaccinated with } 0.5 \\
\text { ml inactivated ND+IB } \\
\text { vaccine (Local } \\
\text { strains) and } 0.1 \mathrm{ml} \mathrm{Cod} \\
\text { liver oil }\end{array}$} \\
\hline 7 days & $0.294 \pm 0.016$ & $\mathbf{A a}$ & $0.293 \pm 0.020$ & $\overline{\mathbf{A b}}$ & $0.289 \pm 0.011$ & $\overline{\mathbf{A b}}$ & $0.294 \pm 0.005$ & $\overline{\mathbf{A b}}$ \\
\hline 21 days & $0.047 \pm .012$ & $\mathbf{B a}$ & $0.116 \pm 0.007$ & Ac & $0.139 \pm 0.012$ & Ac & $0.143 \pm 0.004$ & Ac \\
\hline 35 days & $0.016 \pm 0.001$ & Db & $0.396 \pm 0.051$ & $\mathbf{C a}$ & $0.456 \pm 0.052$ & $\mathbf{B a}$ & $0.519 \pm 0.054$ & Aa \\
\hline
\end{tabular}

Different capital letters refer to significant differences at level $(\mathrm{P} \leq 0.05)$ among mean of groups.

Different small letters refer to significant differences at level $(\mathrm{P} \leq \mathbf{0 . 0 5})$ among periods

The relative increases in bursal index because the bursa of Fabricius is a key lymphoid organ that is responsible for the development and maturation of B-lymphocytes, and the humoral antibody response is dependent on this central organ (56). The results of this study agreed with the results of Lillehoj and Trout (30) who referred the bursa index is the most model was used to estimate protection rate given by vaccines in chicken and the bursa of Fabricius reached the peak of development between the fourth and the twelfth week. However, the bursa of Fabricius one of the unique primary lymphoid organ, which it plays an important role in B cell development and generation of the cellular and immunoglobulin repertoire $(15,10)$.

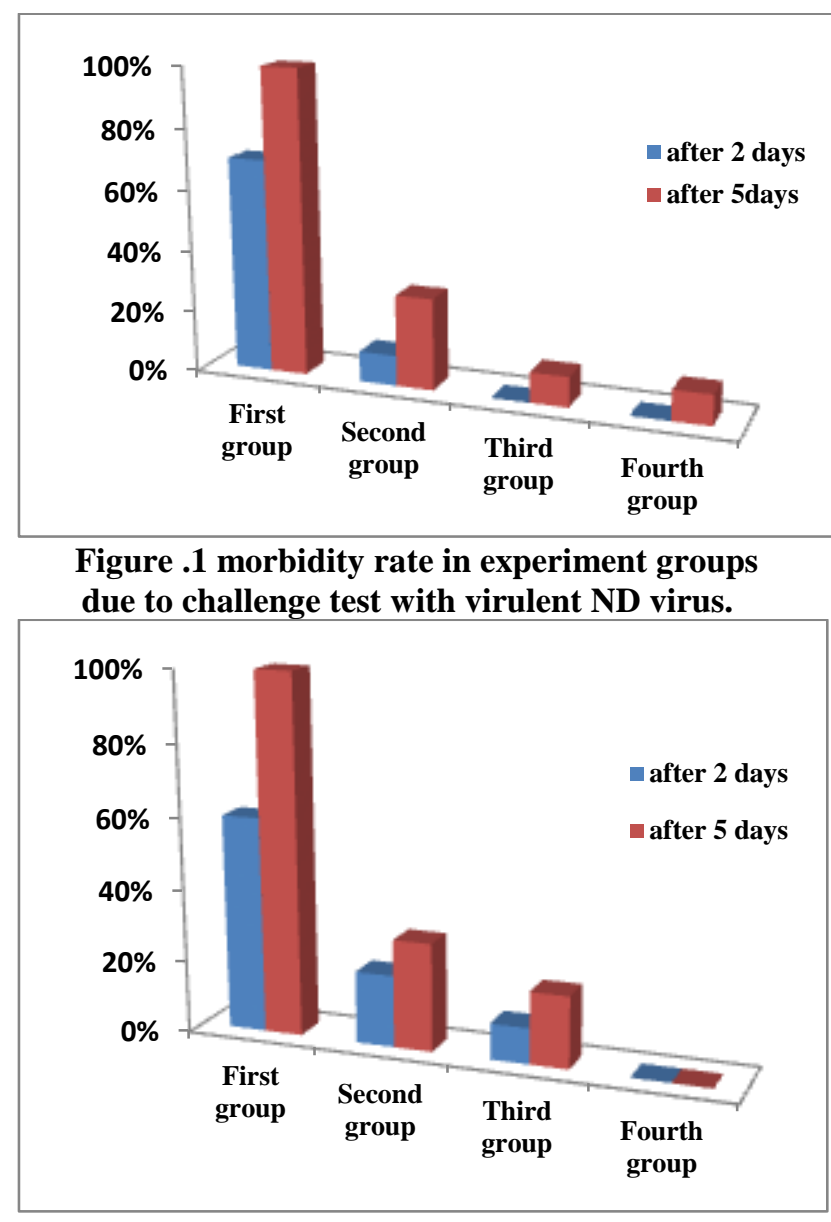

Figure .2 morbidity rate in experiment groups due to challenge test with virulent IB virus.
According to studies carried out $(41,28)$ the bursa of Fabricius increase in volume when the chicken grows, its weight is proportional to the age and with the weight of the subject, until sexual maturity, then it enters a physiological phase of regression; these results are very close to this study. As well as the current results were in agreement with numerous studies (43, 40 and 29). Figure. 1 revealed the morbidity rate arrived $70 \%$ in control group as compared with other groups, while the third and fourth groups did not exhibit any symptoms at two days after challenged with virulent ND virus. But, at five days, the morbidity rate reached $100 \%$ in control group as compared with other treatment groups. The clinical signs were increased gradually and became more severe accompanied with presence of greenish diarrhea in

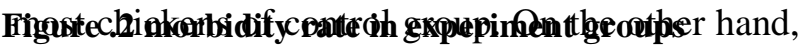
dituento challenge destwitth viruhd andB KBrus:irus, the morbidity rate arrived $60 \%$ in control group were exhibited depression, ruffled feathers and respiratory signs started at 48 hours represented by rales, gasping, sneezing, nasal discharge, wet eye, and conjunctivitis. While, the second group showed morbidity percentage arrived $20 \%$, as well as, the third group was $10 \%$, also the fourth group showed the best protection rate whereas the morbidity rate was zero (Figure 2). In same figure the morbidity rate of first group was increased to $100 \%$ because all the birds were suffered from depression and serious respiratory signs. All vaccinated chicks were showed high protectively specially these which were treated with vaccine, vitamin $\mathrm{E}$ and Cod liver oil (with variance among them) as compared with control. These results matched with the results ELISA test. Alexander (5) suggested that the chicks infected with ND virus led to severe damages in the tracheal epithelium with deciliation of epithelial cells, congestion and inflammatory cells infiltration in the tracheal mucosa at day 4 post inoculation. The current results were in agreement with other researchers $(14,55)$ who inoculated the virulent virus at 14 days of rearing, after two days all chicks in control group showed respiratory signs and depression, as well as, the lesion of dead chicks characterized by 
swollen kidney and severe urate deposition. Ahmed et al., (4) referred the mortality may occur in young chicks due to respiratory or kidney infection after challenged with virulent IB virus. The results of the present study indicate that vitamin $\mathrm{E}$ may change the oxidative stress inside the body and enhanced healthy state of the chicks, these results confirmed the results of Weber et al., (50) that referred that vitamin E used in alleviation of stressful situations that might bird be exposed to through a life period. Vitamin $\mathrm{E}$ affects the humoral and cellular immunity (3). Furthermore, because vitamin $\mathrm{E}$ the best natural antioxidant in the body, it works to prevent the formation of free radicals harmful to body cells and prevent the oxidation of unsaturated fatty acids to maintain the membranes of lymphocytes and macrophages and give the body the ability to resist different bacterial infection (18). On the other hand, the results of fourth group are in agreement with the results of Zhang et al. (57) who explained that role of omega-3 fatty acids as immunity stimulators of cytokines and help B-lymphocytes to increase antibody production with keeping a good body weight gain. From the results of this study, it could be concluded that the supplementation of vitamin $\mathrm{E}$ and Cod liver oil with local bivalent oil based vaccine of Newcastle disease and Infectious bronchitis disease enhance the immune response of the treated chicks particularly these chicks of fourth group which vaccinated with $0.5 \mathrm{ml}$ local bivalent oil based vaccine of ND-IB vaccine and $0.1 \mathrm{ml}$ Cod liver oil was recorded significantly $(\mathrm{P} \leq$ 0.05 ) increase in antibody titer specially at 35 days of age as compared with other study groups.

\section{REFERENCES}

1. Abdulwahid, M.T., 2015. Effect of injection hatching eggs with Newcastle disease vaccine and different doses of vitamin $\mathrm{E}$ on some productive traits and immune response of broilers. The Iraqi Journal of Veterinary Medicine, 39 (2):98-107.

2. Abdulwahid, M.T. and M.A. Al-Zuhairy, 2009. Effect of vitamin (E) supplement to broiler ration on physiological traits and immune response to Newcastle vaccine. Ninth Scientific Conference of Veterinary College, Vol.1.Pp:228.

3. Abdulwahid, M.T. and M.A. Al-Zuhairy, 2013. Effect of injection the broiler hatching eggs with vitamin $\mathrm{E}$ and cod liver oil on some their productive traits and immune response to newcastle disease vaccine. The Iraqi journal of Veterinary Med., 37(2): 199 -205.

4. Ahmad, M. W., Abbas, M. A., I. H. Muneer and A.Hanif, 2007. Immuno- modulatory effects of flumequine and enrofloxacin on newcastle disease virus vaccinated broiler chicks. Pakistan Journal of Life and Social Sciences.5 (1-2), 24-29.
5.Alexander, D.J., 2003. Newcastle Disease Virus and other Paramyxo- viridae Infections. In: "Disease of Poultry". Eds. By Saif, Y. M. associated with Barnes, H. J. Fadly, A.M. Glisson, J. R. McDonald, L. R. and Swayne, D. E., Jr.1 ${ }^{\text {th }}$ Ed., Iowa State University press, Ames, Iowa, USA. Pp: 63-99.

6. Ali, M., Muneer, B., Hussain, Z., Rehmani, S. F., Tahir Yaqub and M. Naeem. 2014. Evaluation of efficacy of killed and commercially available live Newcastle disease vaccine in broiler chickens in Pakistan. The Journal of Anim. and Plant Sci., 24 (6):Pp.:1663-1667.ISSN:1018-7081.

7. Allan, W.H., J.E. Lancaster and B. Toth, 1978. Newcastle Disease Vaccines, their Production and Use. Food and Agriculture Organization of the United Nation, Rome.

8. Basmacioglu, H., Cabuk, M., Ozkan, S., Kocturk, S., G. Oktay and M. Ergul, 2009. Dietary vitamin E ( $\alpha$-tocopheryl acetate) and organic selenium supplementation: performance and antioxidant status of broilers fed n-3 PUFAenriched feeds. South African Journal of Animal Science, 39: (4).

9. Boa-Amponsem, K., Price, S. E. H., P. A. Gerart and P. B. Siegel, 2000. Vitamin E and immune responses of broiler pure line chickens. Poultry Sci., 79: 466-476.

10. Boehm, T. and C. Bleul, 2007. The evolutionary history of lymphoid organs. Nature Immunology. 8,131-135.

11. Calder, P.C., 2010. Omega-3 fatty acids and inflammatory processes. Nutrients, 2:355-374.

12. Calder, P.C., 2012. Omega-3 polyunsaturated fatty acids and inflammatory processes: nutrition or pharmacology? Br J Clin Pharmacol, 75:645662.

13. Cherian, G. and J. Sim, 1992. Preferential accumulation of n-3 fatty acids in the brain of chicks from eggs enriched with n-3 fatty acids. Poult. Sci., 71:1658-1668.

14. Choi, K.S., Kye, S.J., J.Y. Kim and H.S. Lee, 2013. Genetic and antigenic variation of shedding viruses from vaccinated chickens after challenge with virulent Newcastle disease virus. Avian Dis. 2013 Jun; 57(2):303-6.

15. Cooper, M. D., Raymond, D. A., Peterson, R. D., M. A. South and R.A. Good, 1966. The functions of the thymus system and the bursa system in the chicken. J. Exp. Med. 123, 75-102. 16. Diplock A T. 1994. Antioxidants and disease preventation. Mol. Asp. Med. 15:295 -376.

17. Ebeid,T., Fayoud,A., Abou El-Soud,S., Y. Eid and M. El-habbak, 2011. The effect of omega-3 enriched meat production on lipid peroxidation, antioxidative status, immune response and tibia 
bone characteristics in Japanese quail, Czech $\mathrm{J}$. Anim. Sci., 56, (7): 314-324.

18. Erf, G. F., Bottie, W.G., Bersi, T. K., M. D. Headrick and C. A. Fritts, 1998. Effect of dietary vitamin $\mathrm{E}$ on the immune system in broiler, altered proportions of CD4 $\mathrm{T}$ - cell in the thymus and spleen. Poult, Sci., 77: 529-537.

19. Franchini, A., Bertuzzi, S., G. Tosamelli and G. Manfreda, 1995. Vitamin E in viral inactivated vaccines. Poult. Sci.74:666-671.

20. Freidman, A.C., 1997. Effect of dietary fatty acids on humoral immune response of turkeys. Poult. Scie.38. (Abstract).

21. Gore, A. B. and M. A. Qureshi, 1997. Enhancement of humoral and cellular immunity by vitamin E after embryonic exposure. Poult. Sci. 76: 984-991.

22. Grimes, S. E., 2002. A basic Laboratory Manual for the Small-Scale Production, and Testing of 1-2 Newcastle Disease Vaccine. Austr. center for international Agric. Res.

23. Hag, A., C.A. Bailey and A. Chinnah, 1996. Effect of bcarotene, canthaxanthin, lutein, and vitamin $\mathrm{E}$ on neonatal immunity of chicks when supplemented in the broiler breeder diets. Poult. Sci., 75: 1092-1097.

24. Hardman, W. Elaine, 2004. "(n-3) Fatty acids and cancer therapy". Journal of Nutrition 134 (12): 3427 S.

25. Hunkar, T., Aktan, F., A. Ceylan and C. Karasu, 2002. Effects of cod liver oil on tissue antioxidant pathways in normal and streptozotocin - diabetic rats. Cell Biochemistry and Function. 20: 297-302.

26. Korver, D. R. and K. C. Klasing, 1997. Dietary fish oil alters specific and inflammatory immune responses in chicks. J. Nutr. 127:2039-2046.

27. Kumar, U., M. Mishra and V. Prakash, 2012. Assessment of antioxidant enzymes and free radical scavenging activity of selected medicinal plants. Free Radicals and Antioxidants, 2, 58-63.

28. Kuney, 2000. "Bursametre a tool for measuring the size of the Bursa of Fabricius," Solvay animal health. USA.

29. Latif, I. k., H. M. Majed and H. Sahar, 2014. Determine the weight of thymus, bursa of Fabricius and spleen and its ratio to body weight in some diseases of broilers. Mirror of Research in Veterinary Sciences and animals. MRSVA 3 (1), 8-14.

30. Lillehoj, H.S. and J. Trout, 1993. Coccidia: A review of recent Advantages in Immunity and Vaccine development, Avian Pathol., Pp. 22 -23. 31. Lin, Y. F. and S. J. Chang, 2006. Effects of dietary vitamin $\mathrm{E}$ on growth performance and immune response of breeder chickens. Asian-Aust. J. Anim. Sci. 19 (6):884-891.
32. Marja L., M. Mutanen and H.M. Mykkãnen, 1984. Effect of dietary fat on plasma glutathione peroxidase levels and intestinal absorption of 75Se-labeled sodium selenite in chicks. The Journal of Nutrition, 114, 829-834.

33. Marshall, L.H., 1994. The essential omega -6 and omega -3 fatty acids in food. J.Lip.Resea.20: $40-45$.

34. Miret, S., M.P. Sáiz and M.T. Mitjavilo, 2003. Effects of fish oil- and olive oil-rich diets on iron metabolism and oxidative stress in the rat. Br. J. Nutr. 89, 11-18.

35. Murry, R.K., Granner, D.K., P.A. Mayes and V.W. Rodwell, 2006. Harper's Illustrated Biochemistry. Twenty six editions. International edition.

36. Nameghi, A. H., Moghaddam, H. N., J. T. Afshari and H. Kermanshahi, 2007. Effect of vitamin $\mathrm{E}$ and $\mathrm{C}$ supplementation on performance and immune response of broiler chicken. J. Animal Vete. Adv., 6:1060-1069.

37. National Research Council, 1994. Nutrient Requirement for Poultry. 9th revised, Washington. D.C., National Academy Press PP.19-34.3

38. oble, R. C. and M. Cocchi,1990. Lipid metabolism and the neonatal chicken. Prog. Lipid. Res.29:107-140.

39. Petrovsky, N. and J.C. Aguilar, 2004. Vaccine adjuvants: Current state and future trends immunol. cell. Biol., 82: 488-496.

40. Pike, K.A., Iacampo, S., J.E. Friedmann, and M.J. Ratcliffe, 2004. The cytoplasmic domain of Ig alpha is necessary and sufficient to support efficient early B cell development. J. Immunol. 172(4):2210-2218.

41. Ratcliffe, M. J., 2006. Antibodies, immunoglobulin genes and the bursa of Fabricius in chicken B cell development. Dev. Comp. Immunol. 30: 101-118.

42. Sahin, K. and O. Kucuk, 2003. Heat stress and dietary vitamin supplementation of poultry diets. Nutr. Abstr. Rev. Ser. B. Livest. Feeds Feeding, 73: 41R-50R.

43. Sayegh, C.E. and M.J. Ratcliffe, 2000. Perinatal deletion of B cells expressing surface Ig molecules that lack V(D) J-encoded determinants in the bursa of Fabricius is not due to intrafollicular competition. $\mathrm{J}$ Immunol. 164(10):5041-5048.

44. Sellers,R.S.,D.Morton, B.Michael, N.Roome, J.Johnson and K.Schafer, 2007. Society of toxicological pathology position paper: Organ weight recommendations for toxicology studies. Toxicol. Pathol. 35:751-755.

45. Simopoulos, A. P., 1991. Omega-3 fatty acids in health and disease and in growth and development. Am. J. Clin. Nutr. 54: 438-463. 
46. Singh, U., S.Devaraj and I. Jialal, 2005. Vitamin (E), Oxidative Stress, and Inflammation. Annual Review of Nutrition, 25:151-174.

47.Sheffy, B.E. and R.D.Schultz, 1979. Influence of vitamin $\mathrm{E}$ and selenium on immune response mechanisms. Fed Proc. 38 (7):2139-43.

48. Snedecor, G.W. and W.G. Cochran, 1980. Statistical Methods. Iowa State University, press. Iowa.

49. Surai, P.F., Fujihara, N., Speake, P.K., Pbrillard, J., G.J. Wishart and N.H.C.Spark, 2001. Polyunsaturated fatty acids, lipid peroxidation and antioxidant protection in avian semen. Asian Australian J Anim. Sci. 14 (7):1024-1050.

50. Weber, M., Fodor, J., Balogh, K., Wagner, L., M. Erdelyi and M. Mezes, 2008. Effect of vitamin E supplementation on immunity against Newcastle disease virus in T-2 toxin challenged chickens. Acta. Vet. Brno. 77:45-49.

51. Wood, G.W., J.C. Muskett and D.H. Thomton, 1981. The interaction of live vaccine and maternal antibody in protection against infectious bursal disease. Avian Patho., 10: 365373.

52. Yang, X. J., and Y. Guo. 2006. Modulation of intestinal mucosal immunity by dietary polyunsaturated fatty acids in chickens. Food Agric. Immunol., 17:129-137.

53. Yuan Y.V. and D.D. Kitts, 2002. Dietary fat source and cholesterol interactions alter plasma lipids and tissue susceptibility to oxidation in spontaneously hypertensive (SHR) and normotensive wistar kyoto (WKY) rats. Molecular and Cellular Biochemistry, 232, 33-47.

54. Yusuf, S., 2000. Vitamins E. supplementation and cardiovascular events in high-risk patients. The New Eng. J. Med., 20: 154-159.

55. Zahid, A.H., B.H. Ali, and N.S. Ja'fer, 2012. Histopathological study of IBD vaccine in chick embryos. Al.Anbar Journal of Veterinary Sci. Volume (5), No. (1).

56. Zhang, B., Y. Guo and Z. Wang, 2008. The modulating effect of $\beta-1,3 / 1,6$-glucan supplementation in the diet on performance and immunological responses of broiler chickens. Asian-Austr. J. Anim. Sci. 21: 237-244.

57. Zhang, H.X., Zhong, Y.M., H.M. Zhou and T. Wang, 2009. Effect of RRR- $\alpha$-tocopherol succinate on the growth and immunity in broilers. Poult. Sci. 88:959-966. 